\title{
Three Dimensional Reconstruction of Human Sinoatrial Node
}

\author{
Nodus Sinuatrialis'in Üç Boyutlu \\ Rekonstrüksiyonu
}

\section{Ayşegül FIRAT, \\ K. Mine ERBIL, ${ }^{a}$ \\ F. Figen KAYMAZ, \\ Sinan YÜRÜKER, ${ }^{b}$ \\ Semiha ŞEN KAYA, ${ }^{c}$ \\ Selçuk TUNALIa,d}

\section{Departments of}

${ }^{a}$ Anatomy,

bHistology and Embryology,

Hacettepe University Faculty of Medicine,

Ankara

'Department of Psychiatry,

Akdeniz University Faculty of Medicine,

Antalya

'Department of Anatomy,

Physiology \& Biochemistry,

Hawaii University Faculty of Medicine,

Honolulu, HI, USA

Geliş Tarihi/Received: 05.04 .2012

Kabul Tarihi/Accepted: 18.09.2012

This study was presented at the

$10^{\text {th }}$ European Congress of

European Association of Clinical Anatomy,

September 2-5, 2009 in istanbul, Turkey.

Yazışma Adresi/Correspondence:

Ayşegül FIRAT

Hacettepe University Faculty of Medicine, Department of Anatomy,

Ankara,

TÜRKIYE/TURKEY

aysfirat@ hacettepe.edu.tr

\begin{abstract}
Objective: The precise location and structure of the sino-atrial node (SA node) and its relationships with surrounding tissues is uncertain. Therefore, our first aim in this study was to make a real 3D model of the SA node from a human heart to understand the neighborings of the structures that make it. Our second aim was to show numerical data regarding the neighborings so that such data could be useful for clinical procedures. Material and Methods: The SA node was obtained from a formalin-fixed cadaver, embedded in paraffin, $5 \mu \mathrm{m}$ thick complete serial sections were cut and stained with Masson's trichrome stain for demonstrating the it. 3D reconstruction of SA node was generated by using a fully computerized system with XYZ motorized stage and Neurolucida software. Results: SA node was apparent in 90 of 143 histological sections as a crescent-like structure. Nodal myocytes were circumferentially arranged around an obvious central SA nodal artery and embedded in a dense connective tissue. In 3D solid views, we noted the SA node and the SA nodal artery. Crescentlike shaped SA node was located subepicardially between superior vena cava and terminal crest, and it had an extension as a tail toward and parallel to the inferior vena cava. Mean length of the node was $5.04 \mathrm{~mm}$, whereas its width was $1.22 \mathrm{~mm}$. The mean distance of the endocardium to its nearest point to SVC was $0.64 \mathrm{~mm}$, to its nearest point to terminal crest was $2.29 \mathrm{~mm}$, and to the largest part of the node was $0.73 \mathrm{~mm}$. Conclusion: Our findings for the localization, anatomy, histology, and the distribution of cells in the node seem to be comparable to that of the previous studies. We have also showed nodal extensions and nodal artery in this model.
\end{abstract}

Key Words: Sinoatrial node; heart conduction system; image processing, computer-assisted

ÖZET Amaç: Nodus sinuatrialis'in yapısı ve çevre dokularla ilişkisi tam olarak bilinmemektedir. Bu nedenle; çalışmamızın ilk amacı bilgisayarlı bir sistem aracılığı ile, insan nodus sinuatrialis'inin üç boyutlu modellemesidir. İkinci amacımız ise nodus sinuatrialis'i ve çevre yapılar ile ilişkisini klinik işlemlerde kullanılabilecek sayısal verilerle ifade etmektir. Gereç ve Yöntemler: Nodus sinuatrialis formalin ile fikse edilmiş kadavradan çıkarıldı, parafine gömüldü, $5 \mu \mathrm{m}$ seri kesitleri alındı ve Masson trikrom boyası ile boyandı. Nodus sinuatrialis'in üç boyutlu modellemesi, üzerinde hareketli XYZ modülü bulunan bilgisayarlı bir sistem ve Neurolucida programı ile yapıldı. Bulgular: Nodus sinuatrialis; 143 kesitin 90 tanesinde, yarım ay şeklinde bir yapı olarak görüldü. İleti hücrelerinin, ortalarında bulunan arteria nodi sinuatrialis (a. coronaria dextra r. nodi sinuatrialis)'in çevresinde dairesel olarak yerleştiği ve sıkı bağ dokusunun içinde yer aldığı görüldü. Üç boyutlu modellerde nodus sinuatrialis ve arteria nodi sinuatrialis saptandı. Yarım ay şeklindeki nodus sinuatrialis'in, vena cava superior ve crista terminalis arasında, epikardiyumun hemen altında (subepikardiyal) yerleştiği ve vena cava inferior'a doğru, kuyruk şeklinde bir uzantısının olduğu görüldü. Nodus sinuatrialis'in ortalama uzunluğu 5,04 mm, genişliği de 1,22 $\mathrm{mm}$ olarak saptandı. Vena cava superior'a en yakın noktasının endokardiyuma olan ortalama uzaklığı 0,64 mm, crista terminalis'e en yakın noktasının ortalama uzaklığı 2,29 $\mathrm{mm}$ ve en geniş kısmının ortalama boyutu $0,73 \mathrm{~mm}$ olarak hesaplandı. Sonuç: Nodus sinuatrialis'in yeri, anatomisi, histolojisi ve ileti hücrelerinin dă̆ılımı ile ilgili bulgularımızın önceki çalışmalarla uyumlu olduğu görüldü. Ayrıca bu modelde, nodus sinuatrialis'in arteri ve büyük bir uzantısı da gösterildi.

Anahtar Kelimeler: Sinoatriyal nod; kalp iletim sistemi; görüntü işleme, bilgisayar yardımlı

Turkiye Klinikleri J Med Sci 2013;33(2):425-31 
$\mathrm{B}$ eing the pacemaker of the cardiac conduction system with contractile impulses originated in specialized myocytes and conducted via gap junctions between excitable myocytes in various degrees, sino-atrial (SA) node is an elliptic shaped, 10-20 mm long, $1 \mathrm{~mm}$ thick, 3 $\mathrm{mm}$ wide structure located $1-2 \mathrm{~cm}$ to the right side of the crest of the right atrium, and descends postero-inferiorly into the upper part of the terminal crest. ${ }^{1-5}$ Components of this system cannot be differentiated from the atrial muscle tissue by gross dissection; but histologically, nodal cells are discrete from the adjacent atrial muscle cells that arranged around an obvious nodal artery. ${ }^{2}$

SA node consists of small, empty looking, irregularly arranged, subepicardially located specialized myocytes embedded in dense connective tissue. These specialized myocytes are slender and fusiform in shape and are 5-10 $\mu \mathrm{m}$ in diameter. There is a transitional zone between the atrial muscle cells and the nodal cells. ${ }^{1-8}$

Computerized three-dimensional (3D) reconstruction of microscopic structures can be achieved by using histological sections of the specimen. This is necessary for understanding some anatomical structures that are difficult to get detailed information by gross dissection. Computer-based 3D reconstruction allows us to understand microscopic and macroscopic features and relations of the structure with the adjacent tissues.

The aim of the present study was to make a computer-based 3D model of the human SA node and also reveal its microscopic and macroscopic relations with the surrounding tissues.

\section{MATERIAL AND METHODS}

Anatomic position of the SA node is constant in the terminal crest at the junction of the superior vena cava (SVC) and the lateral border of the right atrium. ${ }^{4} \mathrm{~A}$ rectangular block of tissue $(2 \times 2.5 \mathrm{~cm}$ in size) including the distal SVC and atrium on either side of the terminal crest was removed from a formalin-fixed cadaver heart (Figure 1).

First of all, the tissue was processed with increasing series of alcohol and infiltrated in paraffin

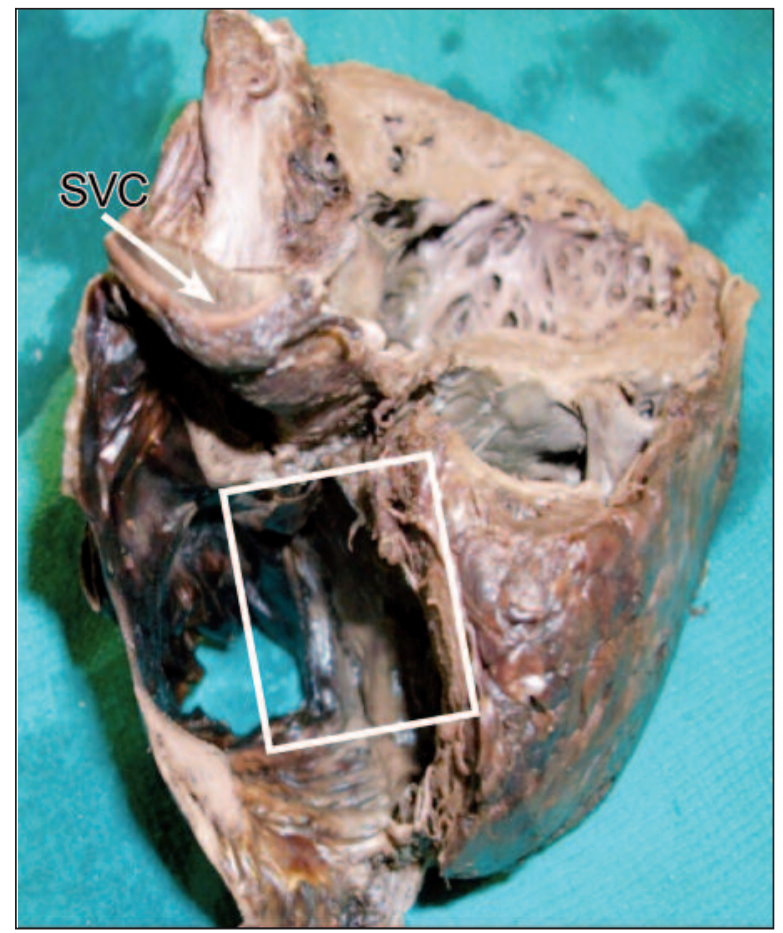

FIGURE 1: A rectangular block of tissue $(2 \times 2.5 \mathrm{~cm})$ was removed between the entrance of superior vena cava (SVC) and the lateral wall of the right atrium.

(See for colored form http://tipbilimleri.turkiyeklinikleri.com/)

with an automated tissue processor (Leica TP 1020). Then it was embedded in paraffin and hardened with tissue embedding center (Leica EG 1150 C \& Leica EG 1150 H). Five $\mu$ m thick serial sections perpendicular to the terminal crest were obtained using a sliding microtome (Leica SM 2000 R). Every 20th section was selected through the compact SA node (section interval: 1/20 sections and block advance: $100 \mu$ ) and finally 143 sections were obtained. Then the sections were stained with Masson's trichrome stain, which includes hematoxylin for staining the nuclei in purple, acid fuchsine for staining muscle fibers in red, and light green for staining collagen fibers in green (Figure 2).

For the microscopic examination, a bright field upright microscope (Leica DM 4000 B), a computer controlled XYZ stage (Ludl MAC 5000) and a digital camera (Optronics Microfire) were used with a software (Microbrightfield Stereo Investigator) and a workstation (IBM IntelliStation Z Pro). Images were captured by $\times 2.5$ objective (Figure 2 ). Since the tissue sections did not fit into the micro- 


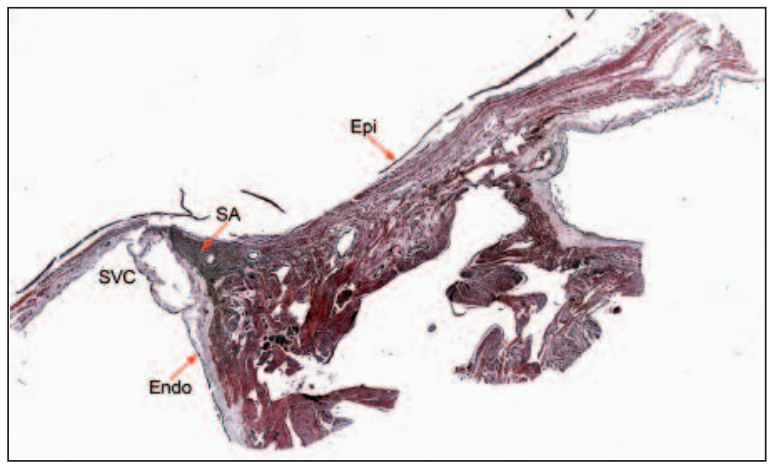

FIGURE 2: One of the 5 micrometer thick histological sections stained with Masson's trichrome. Nuclei are stained in purple, muscle fibers in red, collagen fibers in green. Sinoatrial node appears as a crescent-like structure. Epi: epicardium; endo: endocardium; SA: sinoatrial node; SVC: superior vena cava (48 images of x2.5 microscopic views)

(See for colored form http://tipbilimleri.turkiyeklinikleri.com/)

scopic field of view, an automated system was used for capturing and alignment of the whole tissue. Using the motorized computer controlled XYZ stage, we collected 48 images for each section and merged them into a single high-resolution 2D image, called a virtual slice (Figure 3).

On the histological sections, we made some measurements to provide quantitative information for better understanding the node. The length, width, mean distance of the endocardium to the nearest point of the node to SVC, mean distance of the endocardium to the nearest point of the node to terminal crest, and mean distance of the endocardium to the widest part of the node were measured (Figure 4).

Contour mapping is the basis of tracing. It is performed manually by simple click tracing around the edges of the tissue of interest. Contour mapping is done to evaluate five components in the virtual slices, named endocardium, epicardium, muscle, SA node and SA nodal artery. Each structure was traced in different color for a better differentiation. The user gives the contour name and color. In this step, endocardium and epicardium were traced in blue, muscle in red, SA node in dark green, SA nodal artery in dark red and a big SA nodal extension in green (Figure 5).

For a proper 3D modeling, tracings of each section were aligned to the tissue above, so that they were visualized on top of each other. After the proper alignment by the computerized system, 3D solid views were obtained.

\section{RESULTS}

Within the consequent 143 sections, SA node was identified in the sections from $54^{\text {th }}$ to $143^{\text {rd }}$; in other words, the node was apparent in 90 histological sections. In these sections, SA node was seen as a crescent-like structure (Figure 2). Nodal myocytes were circumferentially arranged around an obvious central SA nodal artery and embedded in a dense connective tissue (Figure 6).

The cells in the center of SA node had small nuclei and were stained pale within a dense con-

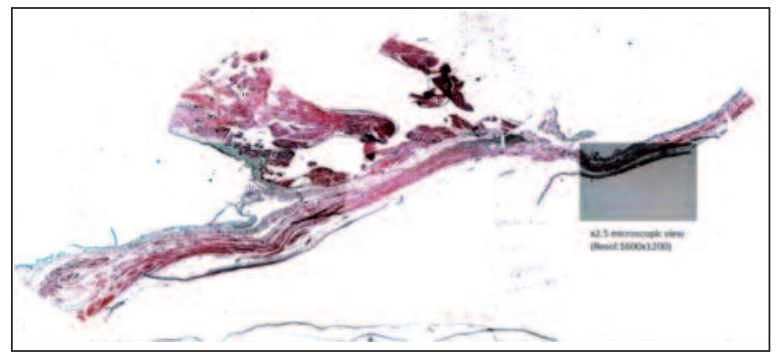

FIGURE 3: Virtual slice: 48 images of $x 2.5$ microscopic fields are merged into a high-resolution image. Total resolution is $10531 \times 5004=51.4$ megapixels for this image (Masson's trichrome stain).

(See for colored form http://tipbilimleri.turkiyeklinikleri.com/)

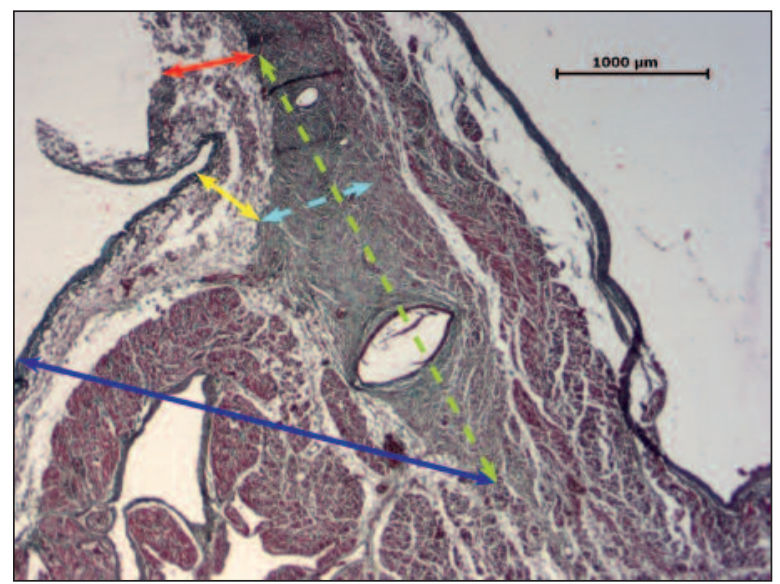

FIGURE 4: A histological section showing the measurements.

Green dashed arrow: Length of the SA node; Cyan dashed arrow: Width of the SA node; Red arrow: Mean distance of the endocardium to the nearest point of the node to the superior vena cava; Blue arrow: Mean distance of the endocardium to the nearest point of the node to crista terminalis; Yellow arrow: Mean distance of the endocardium to the largest part of the node) (Masson's trichrome stain, $\mathrm{x} 10$ original magnification)

(See for colored form http://tipbilimleri.turkiyeklinikleri.com/) 
nective tissue in histological preparations. Outside of these cells, there was a transitional zone including larger cells with bigger nuclei. At the periphery of sections, the atrial muscle cells were seen as biggest cells having dense myofibrils. There were irregularities and projections at the periphery of the node; they were strands of nodal fibers going between the atrial muscle cells (Figure 7).

In 3D solid views, we noted the SA node and the SA nodal artery. Crescent-like shaped SA node was located subepicardially between SVC and terminal crest, and it had an extension as a tail towards and parallel to the inferior vena cava (Figure 2). At the lower sections, we observed that the tail of the node went deeper in the atrial myocardium and became closer to the endocardium. The course of the SA nodal artery was also identified in the histological sections and in the 3D model (Figures 8, 9).

We measured the length, width, maximum and minimum distances to the endocardium to provide quantitative information for better understanding the size of the node (Tables 1, 2).

\section{DISCUSSION}

Immunohistochemical techniques can better demonstrate the distinction between the myocardial cells and the cells of the conduction system, in

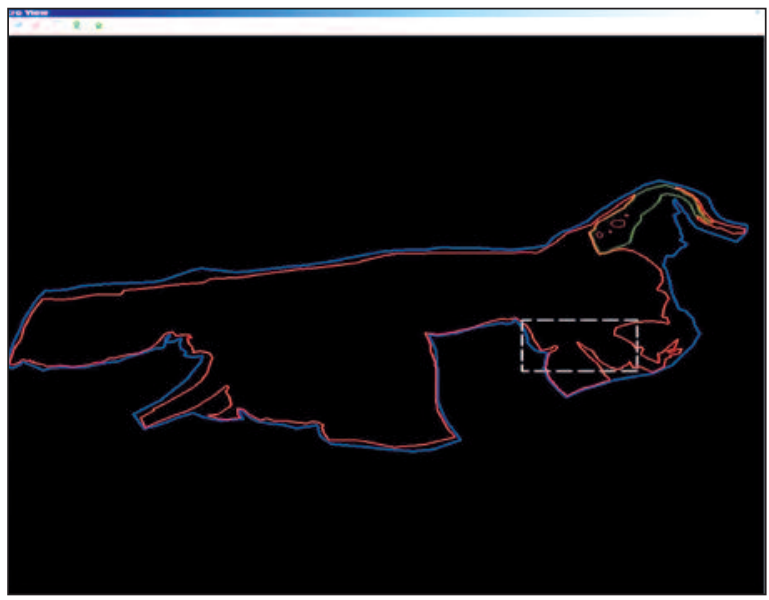

FIGURE 5: Tracing: contour mapping of each structure is done with a different color.

Blue: Endocardium and epicardium; Red: Cardiac muscle; Dark green: SA node; Dark red: SA nodal artery; Green: SA nodal extension.

(See for colored form http://tipbilimleri.turkiyeklinikleri.com/)

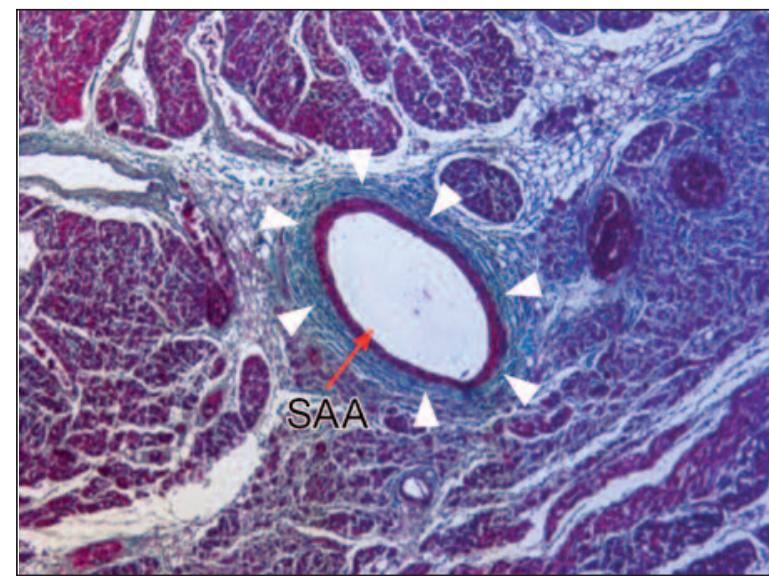

FIGURE 6: Nodal cells are distributed within the SA node. Note the specific circumferential arrangement of nodal cells around the obvious central SA node artery.

SAA: SA node artery; White arrowheads: Nodal cells around the SA node artery. (Masson's trichrome stain, $\times 20$ magnification).

(See for colored form http://tipbilimleri.turkiyeklinikleri.com/)

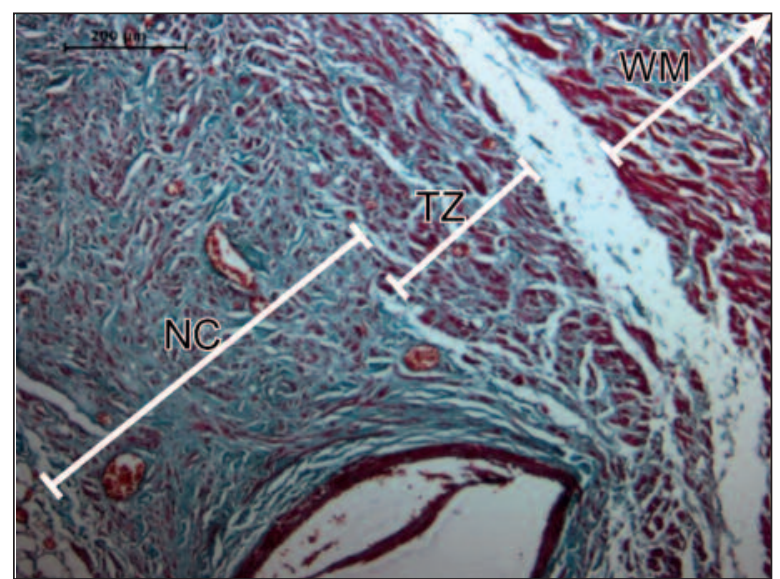

FIGURE 7: Three types of myocytes in and around the SA node.

NC: Nodal cells; TZ: Transitional zone; WM: Working myocytes. (Masson's trichrome stain, $\mathrm{x} 40$ magnification)

(See for colored form http://tipbilimleri.turkiyeklinikleri.com/)

terms of expression of proteins including connexins. ${ }^{2,3,9}$ Distribution of the nodal cells, interaction of myocytes, identification of the SA node histology and anatomy have distinctive features. With this precise knowledge and the development of catheter ablation techniques for the treatment of cardiac rhythm disorders, there is an increasing interest in the morphology and the pacemaker activity of the SA node. ${ }^{9}$ Most of the studies and experiments to explore the morphology and the pacemaker activity of the SA node were done on 


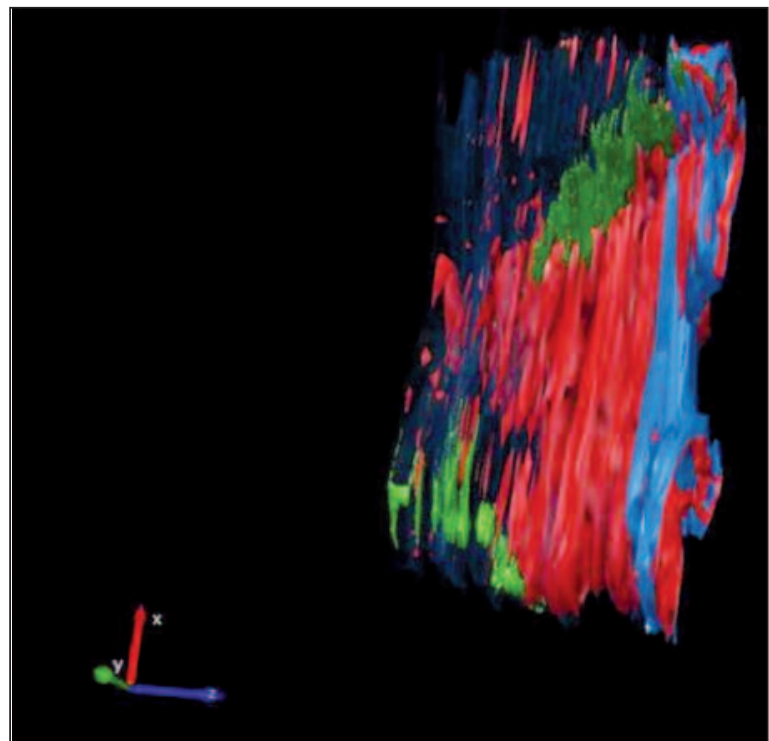

FIGURE 8: 3D model of the specimen.

Green: SA node; Red: Cardiac muscle; Blue: Endocardium and epicardium. (See for colored form http://tipbilimleri.turkiyeklinikleri.com/)

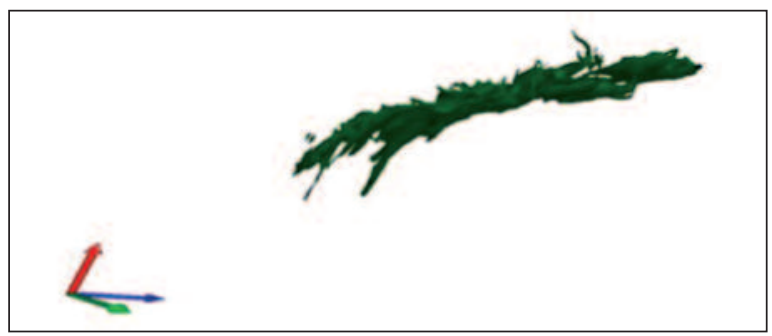

FIGURE 9: 3D model of the SA node when the other structures are removed. (See for colored form http://tipbilimleri.turkiyeklinikleri.com/)

animal models including rabbits, sheep, and rats; because the cellular structure of human SA node is similar to these animal models. ${ }^{2,3,6,8,10-13}$ Three-dimensional models of SA node of human heart will help to understand the integrity, architecture and functional anatomy of the SA node, and guide the planning of catheter ablation techniques for the treatment of cardiac arrhythmias.
The SA node was reported as a crescent-like structure; where the nodal myocytes were smaller and paler than working atrial myocytes, and packed within a dense matrix of connective tissue. ${ }^{2}$ We have used a high resolution imaging technique, and SA node was also seen as a crescentlike structure in our histological sections (Figure 2). Nodal myocytes were circumferentially arranged around an obvious central SA nodal artery and embedded in a dense connective tissue (Figure 6). These findings were also seen in rabbit SA node, as shown with Masson's trichrome stain. ${ }^{9}$ Verheijck et al. showed different types of cells from center to the periphery of the SA node by using immunohistochemistry in the rabbit heart. ${ }^{13}$ Song et al. cultivated SA nodal cells from the newborn rat and showed the cells having three different shapes. ${ }^{11}$ In our study, we also showed three different cell types: the cells in the center of SA node had small nuclei and were stained pale in a dense connective tissue; outside these cells there was transitional zone where bigger cells with larger nuclei were located; at the periphery of sections working myocytes were seen as the biggest cells with dense myofibrils (Figure 7).

Dobrzynski et al. are the first who constructed a 3D anatomical model of the SA node in rabbit using immunohistochemistry, histology and electrophysiology. ${ }^{9}$ They have also identified multiple cell types in the center and periphery of the SA node. Similar to our model, they have also shown

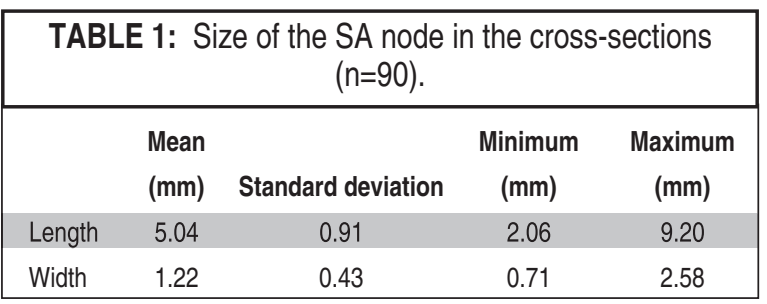

\begin{tabular}{|lcccc|}
\hline \multicolumn{5}{|c|}{ TABLE 2: } \\
\hline & Mean $(\mathrm{mm})$ & Standard deviation & Minimum (mm) & Maximum (mm) \\
\hline From the nearest point to SVC & 0.64 & 0.30 & 0.30 & 2.15 \\
From the nearest point to crista terminalis & 2.29 & 0.11 & 1.06 & 4.51 \\
From the largest part of the node & 0.73 & 0.51 & 0.12 & 2.05 \\
\hline
\end{tabular}

SVC: Superior vena cava. 
the extension of SA node as a tail, running parallel to the inferior vena cava.

Sanchez-Quintana et al. examined 47 human hearts by histological analysis and scanning electron microscopy to study the architecture of human SA node. ${ }^{14}$ They also made some measurements of the node for helping ablation with endocardial modification techniques. We also measured the length, width, maximum and minimum distances to the endocardium, to provide a better understanding for the morphometry of the node with intent to help the ablation and modification procedures of the sinus node when necessary.

Chandler et al., reported that the paranodal area was a unique structure and had properties between the right atrium and the SA node and it may play a role in atrial fibrillation. ${ }^{15}$ In our study, we have also seen a transitional zone located outside the SA node center, and it has histological properties between SA node and right atrium. This transitional zone is the same as the paranodal area. ${ }^{15}$

Sanchez-Quintana et al. measured the size of the SA node in three different parts of the node, namely the head, body and tail; the mean lengths were 2.2, 9.5 and $1.6 \mathrm{~mm}$; and the mean widths were $1.2,1.5$ and $0.4 \mathrm{~mm}$, respectively. ${ }^{14}$ The mean length in our study was $5.04 \mathrm{~mm}$, and the mean width was $1.22 \mathrm{~mm}$. Our results are consistent with those of Sanchez-Quintana et al. ${ }^{14}$ The same researchers measured the distances between parts of the sinus node and the epicardium and endo- cardium. In a majority of their specimens, the inner aspect of the entire node was $<3 \mathrm{~mm}$ in distance to the endocardium. In our study, the mean distance to the endocardium was $<2.29$; thus confirming the study of Sanchez-Quintana et al. ${ }^{14}$ Since the ablation of the SA node is operated through the endocardium, we did not measure epicardial distances of the node. ${ }^{16}$

These results may be helpful in planning ablation and modification procedures of the SA node where clinically indicated.

\section{CONCLUSION}

In our view, 3D model of real human microscopic anatomy accompanied by numerical data will be the gold standart for future anatomical studies. These studies will help the clinicians to better understand the human tissue from real human 3D models in order to develop new procedures for clinical interventions.

\section{LIMITATIONS}

The major limitation of the present study is the use of single cadaver heart in the model consisting of more than a hundred sections and lack of additional information concerning details of the cadaver that the heart was removed from including age, gender and clinical background. Besides, immunohistochemistry for nodal cells can also be performed for accurately mapping the extend of the SA node.

\section{REFERENCES}

1. Standring S. Heart and great vessels. Gray's Anatomy. $40^{\text {th }}$ ed. New York: Elsevier, Churchill Livingstone; 2008. p.975-87.

2. Anderson RH, Yanni J, Boyett MR, Chandler $\mathrm{NJ}$, Dobrzynski $\mathrm{H}$. The anatomy of the cardiac conduction system. Clin Anat 2009;22(1):99113.

3. Sánchez-Quintana D, Yen Ho S. [Anatomy of cardiac nodes and atrioventricular specialized conduction system]. Rev Esp Cardiol 2003; 56(11):1085-92.

4. Mills SE. Normal Heart. Histology for Pathologists. $3^{\text {rd }}$ ed. Philadelphia, Lippincott Williams and Wilkins; 2007. p.574-7.
5. Gartner LP, Hiatt JL. Circulatory System. Textbook of Histology. $3^{\text {rd }}$ ed. Philadelphia: Saunders, Elsevier; 2007. p.267-71.

6. Shimada T, Kawazato H, Yasuda A, Ono N, Sueda K. Cytoarchitecture and intercalated disks of the working myocardium and the conduction system in the mammalian heart. Anat Rec A Discov Mol Cell Evol Biol 2004;280(2): 940-51.

7. Shiraishi I, Takamatsu T, Minamikawa T, Onouchi Z, Fujita S. Quantitative histological analysis of the human sinoatrial node during growth and aging. Circulation 1992;85(6): 2176-84.
8. Anderson $\mathrm{RH}, \mathrm{Ho} \mathrm{SY}$. The architecture of the sinus node, the atrioventricular conduction axis, and the internodal atrial myocardium. J Cardiovasc Electrophysiol 1998;9(11):123348.

9. Dobrzynski H, Lei M, Jones SA, Lancaster MK, Boyett MR. The gradient model of the rabbit sinoatrial node. Korean J Physiol Pharmacol 2002;6(4):173-82.

10. Ryu S, Yamamoto S, Andersen CR, Nakazawa K, Miyake F, James TN. Intramural Purkinje cell network of sheep ventricles as the terminal pathway of conduction system. Anat Rec (Hoboken) 2009;292(1):12-22. 
11. Song Z, Zhong L, Tong S, He G. Primary culture and identification of sinoatrial node cells from newborn rat. Chin Med J (Engl) 2003; 116(3):465-8.

12. Dobrzynski H, Li J, Tellez J, Greener ID, Nikolski VP, Wright SE, et al. Computer three-dimensional reconstruction of the sinoatrial node. Circulation 2005;111(7):846-54.

13. Verheijck EE, Wessels $A$, van Ginneken AC, Bourier J, Markman MW, Vermeulen JL, et al.
Distribution of atrial and nodal cells within the rabbit sinoatrial node: models of sinoatrial transition. Circulation 1998;97(16):1623-31.

14. Sánchez-Quintana D, Cabrera JA, Farré J, Climent V, Anderson RH, Ho SY. Sinus node revisited in the era of electroanatomical mapping and catheter ablation. Heart 2005;91(2): 189-94.

15. Chandler NJ, Greener ID, Tellez JO, Inada $\mathrm{S}$, Musa $\mathrm{H}$, Molenaar $\mathrm{P}$, et al. Molecular architecture of the human sinus node: insights into the function of the cardiac pacemaker. Circulation 2009;119(12):156275.

16. Lafçı B, Yaşa H, Arıkan E, Yılık L, Bayatı K, Bozok Ş, et al. Predictors of sinus rythm restoration by radiofrequency ablation for atrial fibrillation in patients undergoing heart valve surgery. Turkiye Klinikleri J Cardiovasc Sci 2008;20(3):175-9. 